\title{
The Legality of Prisoner of War Labour in England, 1648-1655
}

In July 1653, Oliver Cromwell's secretary of state and spymaster John Thurloe received two troubling letters from the Society of Adventurers, a joint stock company formed to drain the Bedford Level fens just north of Cambridge. As a member and treasurer of the company board himself, Thurloe would have been disturbed but perhaps unsurprised to read the postscript on the covering letter, intended for his eyes only: 'The Dutch prisoners are so stubborn \& they will not work, beinge possest by the Country, that they beinge prisoners at warre, they are to bee mainteyned by them that keepe them.'2 The company had employed Scottish and then Dutch war captives for the past two years. Their prisoners never turned a profit. They did, however, leave this record of their position that their captors had an obligation to maintain them, based on their status as prisoners of war. Their point stands in contrast to the board members' belief that poor prisoners ought to agree to serve those who offered them work.

As captured enemy combatants flooded makeshift prisons throughout England during the wars of the mid-seventeenth century, their keepers devised various strategies to keep them alive, secure, and useful. Most of those who survived were released on parole or exchanged. But thousands of able-bodied common prisoners departed these conditions not for liberty or their graves but rather to serve new masters. Firstly, the Parliamentarian and

\footnotetext{
${ }^{1}$ The research for this article was generously supported by the North American Conference on British Studies, the Huntington Library, and the Frank Knox Memorial Fellowship at Harvard University. I would like to thank Nate Aschenbrenner, Vincent Brown, Paul Clemens, Barbara Donagan, Louis Gerdelan, Tamar Herzog, Joseph la Hausse de Lalouvière, Timo McGregor, Stephanie Mawson, John Morrill, Joan Redmond, David Chan Smith, Scott Sowerby, and the anonymous readers for their astute comments on the manuscript. Shane Bobrycki, Cole Jones, Rena Lauer, Margaret Newell, and Jason Peacey provided valuable research suggestions.

${ }^{2}$ Thomas Birch, ed., A Collection of the State Papers of John Thurloe, Esq., Secretary, First, to the Council of State, and Afterwards to the Two Protectors, Oliver and Richard Cromwell, 1638-1653, 7 vols. (London, 1742), i., 358 (hereafter Thurloe State Papers); original in the Bodleian Library, Oxford, MS Rawl. A 4, p. 236; Timothy Venning, “Thurloe, John (bap. 1616, d. 1668), government official," Oxford Dictionary of National Biography.
} 
subsequent Commonwealth and Protectorate governments used a time-honoured strategy and enlisted captives into their own force. In these cases, the prisoners changed sides and once again became soldiers or sailors. ${ }^{3}$ Military recruitment did not sufficiently lower the populations of prisons, however. Beginning in 1648, the Parliamentarian state transferred some prisoners to the authority of planters, merchants, improvers, and adventurers. These new masters forced the prisoners to work in English naval yards, coal shipping, and fen drainage; Chesapeake and Caribbean plantations; New England ironworks and sawmills; and possibly West African mines. ${ }^{4}$ The captives became servants under contracts to which they were said to willingly agree. With the planters, ironwork company members, and sawmill owners in the colonies, prisoners of war entered multi-year written indentures. With masters in England, including the fen drainage company board, prisoners seem to have formed shorter-term verbal agreements.

In the English Civil Wars, the laws of war around prisoners never stabilized. This instability created an opening for the concept of consensual, compulsory service to extend from paupers to common war captives. Employers bothered to create contracts with the men who had little choice but to work for them in part as an expedient extension of established

\footnotetext{
${ }^{3}$ It was perfectly possible and widely accepted for common sailors and foot soldiers to switch sides in the period. Those who originally entered one force due to an ideological allegiance could change their minds. Others were motivated by the promise of pay, shelter, and food, or had been impressed and had never chosen to enlist in the first place: Andrew Hopper, Turncoats and Renegadoes: Changing Sides During the English Civil War (Oxford, 2012), Ch. 4. Hopper notes that contemporaries disapproved of 'enticing' war prisoners to turn coat but approved if they did so 'voluntarily,' 85-87. For military service as labour see, for example, Erik Jan Zürcher, Fighting for a Living: A Comparative History of Military Labour 1500-2000 (Amsterdam, 2013); Way, "Militarizing the Atlantic World: Army Discipline, Coerced Labor, and Britain's Commercial Empire," Atlantic Studies 13, no. 3 (July 2016): 345-69.

${ }^{4}$ Abbot Emerson Smith, Colonists in Bondage: White Servitude and Convict Labor in America, 16071776 (Chapel Hill, 1947), 152-57; Malcolm Atkin, Cromwell's Crowning Mercy: The Battle of Worcester 1651 (Stroud, 1998), 129-38; Gijs Rommelse and Roger Downing, 'Victims of an Ideological Rift? Dutch Prisoners of War during the First Anglo-Dutch War (1652-1654), Journal of Military History 80, no. 3 (July 2016): 64969 at 663. Bulstrode Whitelocke, Memorials of the English Affairs from the Reign of Charles I to Charles II, 4 vols., (Oxford, 1853), iii, 354 notes that in October 1651, 1,500 Scots were sent to work in mines by the 'Guinea merchants,' although Samuel Rawson Gardiner, History of the Commonwealth and Protectorate, 1649-1656, 4 vols. (New York, 1894-1903), ii, 63, and Smith, Colonists in Bondage, 156, doubted that this plan was carried out.
} 
practices of social control and labour extraction, and in part as a justification for the conscription of men who had good claims to protection. The English governments and company board members ignored protections for prisoners of war from the ius gentium (the law of nations). They did not explicitly write about the laws they chose to use instead, but their actions show that they followed the logic of statutory poor law, within which prisoners could make legitimate contracts. The prisoners' contracts played a key role in the changing mentalities around coercion and labour in the seventeenth century. Free contract soon extended beyond the war between Englishmen, to the Scots, the Irish, and, in a more limited fashion, the Dutch. While resistance to work and transportation is evident in all of these groups, the Dutch best articulated their objections. They called their labour forced-not free. This article examines the specific chronology and context of the employment of prisoners of war by English masters in the Bedford Level of East Anglia and further afieldfrom Massachusetts to Barbados. This approach requires pairing well-trodden sources in the English state papers with those that have not yet been utilized for the study of coercion and labour. Atlantic historians have long folded the plantation servitude of European prisoners of war into the broader story of forced migration in the early English empire, upholding a consensus that transportation of a range of vulnerable people was a key strategy in English colonization during and after the Interregnum. ${ }^{5}$ While the narrative of the upswing in forced migration for the mid-century stands, it matters that contemporaries themselves understood

\footnotetext{
5 The classic statement is Vincent T. Harlow, A History of Barbados, 1625-1685 (Oxford, 1926), 117, expanded in Smith, Colonists in Bondage, Chs. 5, 7 and 8. See also Hilary McD. Beckles, White Servitude and Black Slavery in Barbados (Knoxville, 1989), 46; Peter Wilson Coldham, Emigrants in Chains: A Social History of Forced Emigration to the Americas, 1607-1776 (Stroud, 1992); David Eltis, 'Labour and Coercion in the English Atlantic World from the Seventeenth to the Early Twentieth Century,' Slavery \& Abolition 14, no. 1 (1993): 207-226; Carla Gardina Pestana, The English Atlantic in an Age of Revolution, 1640-1661 (Cambridge, Mass., 2004), 157 and Ch. 6; Alison Games, The Web of Empire: English Cosmopolitans in an Age of Expansion, 1560-1660 (New York, 2008), 257; John Donoghue, Fire under the Ashes: An Atlantic History of the English Revolution (Chicago, 2013), 215-17; Abigail Leslie Swingen, 'Labor: Employment, Colonial Servitude, and Slavery in the Seventeenth-Century Atlantic,' in Mercantilism Reimagined: Political Economy in Early Modern Britain and Its Empire, ed. Philip J. Stern and Carl Wennerlind (New York, 2013), 48-53.
} 
the labour conscription of Christian war captives to be a legal problem distinct from that of the penal transportation of civilian convicts and the enslavement of African or Native American captives. ${ }^{6}$ The competing ways to handle prisoners of war and their labour generated records that give us unusual insight into how people thought about forced labour, precisely as English colonization, slave trading, and slave owning expanded, and just before large-scale convict transportation began. Meanwhile, Atlanticists and early Americanists, for all their interest in transportation, have largely ignored the contemporaneous labour conscription in England of prisoners from the same battles and backgrounds as the transported war captives. ${ }^{7}$

Prisoner of war labour in England remains neglected, receiving only brief treatment in scholarship on the history of the drainage projects and of various related battles. ${ }^{8}$ Early modern military historians have simply noted instances of prisoner labour within their work on the changing nature of warfare in England and Europe. I build, however, on their point that combatants managed warfare through contracts - with terms set by the international, customary laws of war, by articles of war propagated by commanders, and by cartels struck by diplomats who arranged exchanges of prisoners. Barbara Donagan's 1988 insight that 'The primary function of the laws of war by the seventeenth century was as a kind of

${ }^{6}$ J. M. Beattie, Crime and the Courts in England, 1660-1800 (Princeton, 1986), 472; Eliga H. Gould, 'Zones of Law, Zones of Violence: The Legal Geography of the British Atlantic, c. 1772,' The William and Mary Quarterly 60, no. 3 (2003): 506-507; Timothy J. Coates, 'European Forced Labor in the Early Modern Era,' in The Cambridge World History of Slavery, ed. David Eltis and Stanley L. Engerman, vol. 3 (Cambridge, 2011), 631-49; Hamish Maxwell-Stewart, 'Convict Transportation from Britain and Ireland 1615-1870,' History Compass 8, no. 11 (2010): 1224-25; Jeffrey Glover, 'Witnessing African War: Slavery, the Laws of War, and Anglo-American Abolitionism,' The William and Mary Quarterly 74, no. 3 (2017): 504-5.

${ }^{7}$ Brief mentions of the fen draining prisoners in the context of transatlantic transportation may be found in Smith, Colonists in Bondage, 156, and David Eltis and Stanley L. Engerman, 'Dependence, Servility, and Coerced Labor in Time and Space,' in The Cambridge World History of Slavery, ed. Eltis and Engerman (Cambridge, 2011), 4-5.

${ }^{8}$ Samuel Wells, The History of the Drainage of the Great Level of the Fens (London, 1830), 228, 249 50; Lindley, Fenland Riots, 175-77; Eric H. Ash, The Draining of the Fens: Projectors, Popular Politics, and State Building in Early Modern England (Baltimore, 2017), 268-69 and 272; Rommelse and Downing, 'Victims,' 663; Atkin, Cromwell's Crowning Mercy, 333, 336-37. 
contractual etiquette of belligerence' remains influential. ${ }^{9}$ However, as we shall see, these same laws of war forbid setting prisoners into hard labour. It was another form of contract one for free labour, not for restrained fighting — that justified captives' servitude.

The method I follow here suggests how archives often thought of as strictly the concern of domestic or even provincial English history might illuminate the changing concepts of legitimate labour relations not only in England but also in the English colonies. I draw primarily upon the Bedford Level Corporation records, in coordination with the Council of State minute books, state correspondence, and records to do with the City of London and its merchants. The temporal focus is on 1648 to 1655 because the number of war prisoners in English custody reached unmanageable levels in this period, such that the new regimes had cause to experiment with different approaches. Precisely because they were new regimes of dubious authority, they were under constant criticism. Their critics produced a further source base that articulated why setting war captives to work might be wrong.

The language of willing contract invoked by the employers of war captives came out of English poor law ideology. This conceptual approach allowed masters to side-step the customary laws of war, which prohibited hard labour for Christian prisoners. With contracts, masters in effect re-classified their charges' status from common prisoner, to pauper, to servant. This transformation hinged on the idea that imprisonment had made these men dependent on charity and therefore desperate for employment. Dependency made common war captives consent when they had no option to refuse. While under English contract law, free people — in the contemporary sense of that term — could not form valid contracts under

\footnotetext{
${ }^{9}$ Barbara Donagan, 'Codes and Conduct in the English Civil War,' Past \& Present 118, no. 1 (February 1988): 78-79. See also Maurice Hugh Keen, The Laws of War in the Late Middle Ages (London, 1965), Ch. 10; Barbara Donagan, "Prisoners in the English Civil War," History Today, March 1, 1991; Geoffrey Parker, 'The Etiquette of Atrocity: The Laws of War in Early Modern Europe,' in Empire, War and Faith in Early Modern Europe (London, 2002), 143-68; Rémy Ambühl, Prisoners of War in the Hundred Years War: Ransom Culture in the Late Middle Ages (Cambridge, 2013); and Stephen Conway, 'Moral Economy, Contract, and Negotiated Authority in American, British, and German Militaries, ca. 1740-1783,' The Journal of Modern History 88, no. 1 (March 2016): 34-59.
} 
duress, this principle simply did not apply to paupers. ${ }^{10}$ The English poor, when they refused to serve, could be subjected to the pillory and imprisonment until they consented to contract with a master or mistress; those accused of vagrancy could be whipped and sent to houses of correction; pauper children could be placed into parish apprenticeships until their early twenties. ${ }^{11}$ In the mid-century, masters expanded this dynamic to procure 'willing' prisoners of war. Not only did they think of common prisoners of war as able to consent to serve without the option to refuse, they also thought of poor commoners (including prisoners) as natural labourers who ought to serve their social superiors. In this ideological context, the many competing laws that could be brought to bear on such prisoners exposed them to coercion more effectively than they extended protection. Most prisoners could not effectively leverage their claim that their servitude was illegal, although the Bedford Level case is proof that they tried.

\section{I}

\section{The Legal Context of Prisoner of War Labour}

The rules on how lower-status prisoners of war in the seventeenth century could be made to work drew on a long legal tradition. In ancient Roman law, war captives could be legally enslaved. ${ }^{12}$ This rule continued to be used selectively as part of the law of nations in the early modern period. The English invoked just war when they enslaved Africans and indigenous people, and the English themselves were enslaved in the Ottoman empire under the same

\footnotetext{
${ }^{10}$ Simpson, A History of the Common Law of Contract, 99; Keen, The Laws of War, 180-81; Jean Dunbabin, Captivity and Imprisonment in Medieval Europe, 1000-1300 (Houndmills, 2002), 94; Ambühl, Prisoners of War, 45.

${ }^{11}$ The Statute of Artificers, 5 Eliz. c. 4; Audrey Eccles, Vagrancy in Law and Practice under the Old Poor Law (Farnham, 2012), 1-3; Steve Hindle, On the Parish?: The Micro-Politics of Poor Relief in Rural England, c. 1550-1750 (Oxford, 2004), 191-223.

12 J.B. Moyle, trans., The Institutes of Justinian, 5th ed. (Oxford, 1913), 6 (Book I, Title 3); Jane F. Gardner, "Slavery and Roman Law," in The Cambridge World History of Slavery, ed. Keith Bradley and Paul Cartledge (Cambridge, 2011), 415.
} 
rule. ${ }^{13}$ Beginning in the ninth century, enslavement of captives had been officially prohibited in warfare amongst Latin Christians. ${ }^{14}$ This principle had extended to include Orthodox Christians, more in word than deed in the fourteenth century, but comprehensively by the sixteenth century. ${ }^{15}$ While enslavement and sale of persons was forbidden, lower-status Christian prisoners of war might perform forced labour for their masters while waiting to be ransomed or exchanged. ${ }^{16}$

Prisoners of war became categorically distinct from another category of people in captivity: accused and convicted criminals. Unlike criminals, imprisoned enemy combatants could hope for honourable treatment. ${ }^{17}$ The fourteenth-century refinement of the idea of just war as one declared between authorized sovereigns, as opposed to powerful barons in a private conflict, solidified the notion that a soldier was doing his duty for a king by fighting. Accordingly, the ideal for the treatment of captured enemy combatants also shifted. Dutiful soldiers should not be imprisoned as punishment. Their service to their sovereign showed

${ }^{13}$ Gould and Glover, op. cit., and Thomas D. Morris, Southern Slavery and the Law, 1619-1860 (Chapel Hill, 1996), 19-20. The relevance of the laws of war to English enslavement by corsairs is implied in Catherine M. Styer, "Barbary Pirates, British Slaves, and the Early Modern Atlantic World, 1570-1800' (University of Pennsylvania, 2011), 193. The Ottomans shared aspects of the ius gentium; it was not exclusively European or Christian.

${ }^{14}$ Michael McCormick, 'New Light on the "Dark Ages": How the Slave Trade Fuelled the Carolingian Economy,' Past \& Present 177, no. 1 (November 2002): 47.

${ }^{15}$ Debra Blumenthal, Enemies and Familiars: Slavery and Mastery in Fifteenth-Century Valencia (Ithaca, 2009), 33-39 shows that in the fourteenth- and fifteenth-century Crown of Aragon, laws against enslaving Orthodox Christian captives remained in force only briefly and had little effect on practice. Christopher L. Tomlins attributes this principle primarily to the early sixteenth-century Spanish jurist Francisco de Vitoria in Freedom Bound: Law, Labor, and Civic Identity in Colonizing English America, 1580-1865 (Cambridge, 2010), 127-28, following Anthony Pagden, The Fall of Natural Man: The American Indian and the Origins of Comparative Ethnology (Cambridge, 1982). By the late sixteenth century, Luis de Molina considered the customary law that forbade Christian enslavement of Christians to be well established: see Matthias Kaufmann and Alexander Aichele, eds., A Companion to Luis de Molina (Leiden, 2014), 195. Tomlins, 421, further points to Alberico Gentili's discussion of the principle against enslaving Christian captives, written in England in the 1580s. By 1625, Hugo Grotius took the principle as firmly established in The Rights of War and Peace, ed. Richard Tuck and Jean Barbeyrac, 3 vols. (Indianapolis, 2012), 1371 (Book 3, Ch. 7). See also Barbara Donagan, War in England 1642-1649 (Oxford, 2008), 139; Peter Wilson, "Prisoners in Early Modern European Warfare," in Prisoners in War, ed. Sibylle Scheipers (Oxford, 2010), 39-56, at 45; Renaud Morieux, 'Le dilemme de la sentinelle. Droit de la guerre et droits des prisonniers de guerre en GrandeBretagne au XVIIIe siècle,' Revue d'histoire moderne et contemporaine 64, no. 2 (September 2017): 39-68 at 63 .

${ }^{16}$ Dunbabin, Captivity and Imprisonment, 86-87; Keen, The Laws of War, 161-62.

${ }^{17}$ Ambühl, Prisoners of War, 4 and 120. 
them to be morally upright in their obedience, and so deserving of good treatment. But they might be held captive to strategically weaken their side and sustain diplomatic negotiations for exchanges. ${ }^{18}$

According to the Bedford Level company's July 1653 letters to Thurloe, the Dutch prisoners referred to this accretion of legal custom, which relied on no written code for its authority. In the $1650 \mathrm{~s}$, the most widely cited treatise to invoke this custom was Hugo Grotius's 1625 De Iure Belli ac Pacis (The Rights of War and Peace). Grotius included a passage in which he argued that in war between Christians, 'it is generally agreed, that being engaged in War, they that are taken Prisoners, are not made Slaves, so as to sell them or force them to hard Labours, or to such Miseries as are common to Slaves, and that with Reason; for they are, or should be better instructed by the great Recommender of every Act of Charity.' 19 The merciful act of sparing an enemy's life to take him as a prisoner was cancelled out if one then forced him to do hard labour. The prohibition was limited to hard labour and miserable conditions. Prisoners of war might be legally set to reasonable service, according to this reading. What constituted hard labour remained open to interpretation and dispute. The labourers mentioned in the letter to Thurloe thought that the construction of dykes fell well within the definition, but the company members disagreed.

However, as seen in the letter to Thurloe, people did not need to have read Grotius or his sixteenth-century predecessors Vitoria, de Molina, and Gentili to know about the prohibition of Christian slavery. ${ }^{20}$ With hard labour came the guarantee of indignity, and the severe threat of injury, displacement, and death. Commoners with connections to military life — virtually everyone in this decade — had good reason to cherish its prohibition for prisoners of war. They may have been thinking of the prohibition as an expression of

\footnotetext{
${ }^{18}$ Dunbabin, Captivity and Imprisonment, 8-10, 86-87; Ambühl, Prisoners of War, 149.

${ }^{19}$ Grotius, The Rights of War and Peace, 1371 (Book 3, Ch. 7).

${ }^{20}$ See n. 15.
} 
confessional fraternity, but also as an ethics of warfare. Those who served in the burgeoning armies and navies of the mid-seventeenth century valued the recognition of honour for war prisoners in distinction to imprisoned convicts or those held in custody awaiting felony trials. ${ }^{21}$ Such an approach also prevented retribution against one's own men, should they be taken captive by the opposing force.

In the late 1640 s the Parliamentarian state nevertheless found the number of prisoners under their control too many to fit in available prisons, too expensive to feed and maintain, but too strategically valuable to release, and perhaps too tempting not to use for profit. It turned to the labour conscription and transportation of war captives. Given the legal context, this turn required a side step around the ius gentium and encouraged captors to look elsewhere for legal justification.

\section{II}

\section{Prisoners' Service and Transportation under Contract}

From 1648, regime change and the upheaval of war created an environment in which the Parliamentarian and subsequent Interregnum authorities extended a decades-old practice of transporting socially undesirable people to the American colonies by allowing merchants to transport captives from besieged garrisons and battlefields. ${ }^{22}$ They also encouraged companies and private masters within the British Isles to employ these prisoners closer to home — as they did with impoverished civilian subjects. The state and its collaborators conceptualized nearly all of these prisoners, whether bound for the colonies or employed in

\footnotetext{
${ }^{21}$ Barbara Donagan, 'The Web of Honour: Soldiers, Christians, and Gentlemen in the English Civil War,' The Historical Journal 44, no. 2 (June 2001): 384.

22 Smith, Colonists in Bondage, 89-95; R.C. Johnson, 'The Transportation of Vagrant Children from London to Virginia, 1618-1622,' in Early Stuart Studies, ed. H.S. Reinmuth (Minneapolis, 1970), 137-51; Beckles, White Servitude, 56-57; Joanna Innes, 'The Role of Transportation in Seventeenth- and EighteenthCentury English Penal Practice,' in New Perspective in Australian History, ed. Carl Bridge (London, 1990), 812; Sandra L. Dahlberg, "Doe Not Forget Me" Richard Frethorne, Indentured Servitude, and the English Poor Law of 1601,' Early American Literature 47, no. 1 (2012): 1-30.
} 
England, with the same principle: captured commoners were able to consent to serve. Their social status and poverty left them no alternative.

Parliament began to authorize the transportation of captured soldiers in the final months of the Second Civil War. State papers hold sparse details about these transportations, but some details can be filled in with records held elsewhere. On 8 July 1648 the House of Commons ordered the committee for prisoners to "take speedy and effectual Course for the Disposing of the common Prisoners, taken in the late Insurrections, into the Plantations beyond the Seas." ${ }^{23}$ After the Parliamentarians defeated the royalist Duke of Hamilton's forces at the Battle of Preston in August, a newsletter reported that an unspecified number of the captured Scottish soldiers were to be "sold for two shillings a piece to be carried to new Plantations." ${ }^{24}$ Who exactly did the selling and buying was ambiguous. Most likely, the word "sold" arose because planters and other would-be-masters in the colonies paid the middlemen, including factors and ship captains, who arranged for the prisoners to be shipped west. No known record shows that the government charged or received money for prisoners. The state did, however, save a great deal on the cost of prisoner maintenance, and promoted entrepreneurial and colonizing projects it held to be in the interest of the commonwealth.

In 1649, with the abolition of the House of Lords and the execution of Charles I, the new Commonwealth state looked to solidify its power over Scotland, Ireland, and the colonies. At first, sending prisoners of war across the ocean to serve colonial planters played a small role in this process. Beyond the transportation of two ships of Scottish soldiers after the Battle of Preston and nineteen English royalists from Colchester, the only other evidence for transported war captives in 1648 to 1649 is from Oliver Cromwell, who reported that Irish

\footnotetext{
C.J., vi, 5.

${ }^{23}$ Journal of the House of Commons (hereafter C.J.), (London, 1802), v, 629, see also 632 and 635 and

${ }^{24}$ Thomas Carte, ed., Collection of Original Letters and Papers...found among the Duke of Ormonde's Papers, 2 vols. (London, 1739), i, 177.
} 
prisoners were transported to Barbados after the siege of Drogheda in September 1649. The precise number is not known. ${ }^{25}$ However, following the battles of Dunbar in September 1650 and Worcester in September 1651, these numbers increased. The English Commonwealth now ruled Scotland. Cromwell's army claimed to have captured 10,000 Scottish soldiers after each battle. ${ }^{26}$ Although many of the sick and wounded went home, thousands more remained in custody, a drain on the resources and a cause of anxiety for the Council of State.

The scale of prisoners' labour conscription then expanded significantly — both in England and the colonies. Arthur Haselrigge reported that of the 5,000 prisoners marched from Dunbar to Newcastle, most succumbed to an epidemic of the flux but, 'I have granted to several well-affected persons that have Saltworks at Sheels, and want Servants, Forty, and they have engaged to keep them to work at their Salt-pans; and I have taken out more about Twelve Weavers, to begin a Trade of Linnen cloth like unto the Scotch-cloth, and about Forty Laborers. ${ }^{27}$ These ninety-two men worked in England and Scotland. More than 400 Scots from Dunbar and Worcester were transported to Massachusetts and then distributed further afield. They became a crucial component of the labour force in New England iron works, sawmills, farming, and trade. ${ }^{28}$ Those who worked for the Adventurers for the Ironworks in

${ }^{25}$ W.C. Abbott, ed., The Writings and Speeches of Oliver Cromwell, 4 vols. (Cambridge, Mass., 19371947), ii, 127. See also Hilary McD. Beckles, 'A "riotous and Unruly Lot": Irish Indentured Servants and Freemen in the English West Indies, 1644-1713,' The William and Mary Quarterly 47, no. 4 (1990): 506-507; Micheál Ó Siochrú, God's Executioner: Oliver Cromwell and the Conquest of Ireland (London, 2008$), 86$. Cromwell did not specify whether the transportees entered indentures before departure, but it is reasonable to assume that they eventually entered contracts, which organised master-servant relationships in Barbados.

${ }^{26}$ A Brief Narrative of the Great Victorie, Which It Hath Pleased God to Give to the Armie of This Common-Wealth against the Scots Armie, near Dunbar (London, 1650, STC R206480); Whitelocke, Memorials of the English Affairs, iii, 348; Atkin, Cromwell's Crowning Mercy, 123.

${ }^{27}$ A Letter from Sir Arthur Hesilrige, to the Honorable Committee of the Councel of State for Irish and Scotish Affairs at White-Hall, Concerning the Scots Prisoners (London, 1650, STC R206705), 6-7.

${ }^{28}$ C.E. Banks, 'Scotch Prisoners Deported to New England by Cromwell, 1651-52,' Proceedings of the Massachusetts Historical Society 61 (October 1927): 4-29; Stephen Innes, Labor in a New Land: Economy and Society in Seventeenth-Century Springfield (Princeton, 1983), 85-86, 143; Marsha L. Hamilton, Social and Economic Networks in Early Massachusetts: Atlantic Connections (University Park, Pa., 2009), 35-50. For orders to transport Scots (an indeterminate number of which were carried out) see CSPD 1651, 431-33 (The National Archives, London [hereafter TNA], SP 25/22, p. 52 and 55); CSPD 1651, p. $443-44$ (TNA, SP 25/96, p. 547); CSPD 1651, 480 (TNA, SP 25/23, p. 44); TNA, SP 25/23 p. 51, 21, and W. Noel Sainsbury, ed., Calendar of State Papers: Colonial Series (CSP Col.), vol. 1, (London, 1860), 363. 
Lynn and Saugus, Massachusetts appear often in surviving records, which referred to them by the ethnonym 'Scotts' and never as prisoners. Their transition from prisoners to servants was complete, at least for accounting purposes. ${ }^{29}$ Perhaps 1,000 or more Scottish prisoners of war went to Barbados. ${ }^{30}$ More than 1,500 Scots were ordered to Virginia a couple years later, but far fewer seem to have actually gone. ${ }^{31}$ Records of licences survive for the transportation of 700 Irish war captives to the West Indies, although again it remains unclear how many went. $^{32}$

The legal rationale for transporting some war captives into colonial servitude had to be selected from two options. Either prisoners were treated as criminals and sent to work as a commutation of capital punishment, typically handled as reprieve but increasingly as a pardon, or they were free agents able to willingly form labour contracts from jail. ${ }^{33}$ The English state generally did not frame prisoner of war labour as a commuted sentence or pardon in this period. The Drogheda case suggests how this rejected approach could have worked. In a 16 September 1649 letter, Oliver Cromwell wrote about the siege to William Lenthall, the speaker of Parliament: 'When they submitted, their officers were knocked on the head, and every tenth man of the soldiers killed, and the rest shipped for the Barbadoes. The soldiers in the other tower were all spared, as to their lives only, and shipped likewise for

\footnotetext{
${ }^{29}$ Harvard Business School, Baker Library, Cambridge, Mass., Company of Undertakers of the Irons Works in New England: Records of the iron works at Lynn, Mass., 1650-1686: Microfilm Order no. $72-792$. This collection will soon be digitized and published in Harvard Library's Colonial North America Project.

${ }^{30}$ Harlow, A History of Barbados, 117, 294-95, Smith, Colonists in Bondage, 152-57, and Beckles, White Servitude, 53-4. See also Heinrich Von Uchteritz, 'A German Indentured Servant in Barbados in 1652,' edited and translated by Alexander Gunkel and Jerome S. Handler in The Journal of the Barbados Museum and Historical Society 33, no. 3 (May 1970): 92. Von Uchteritz claimed that after the Battle of Worcester he and 1,300 men were imprisoned in London for a quarter of a year and then transported to Barbados and sold as servants. Scholarship has not confirmed this number. Barbados planters claimed that they had employed 12,000 prisoners of war, although this number is surely inflated: British Library, London, Add. MS 11411, f. $9^{\mathrm{r}}$.

31 TNA, SP 25/22, p. 42 and CSP Col., i, 360; Smith, Colonist in Bondage, 156-57.

${ }^{32}$ Smith, Colonist in Bondage, 164-65.

${ }^{33}$ Cynthia B. Herrup, 'Punishing Pardon: Some Thoughts on the Origins of Penal Transportation,' in Penal Practice and Culture, 1500-1900: Punishing the English, Simon Devereaux and Paul Griffiths (eds.), (Houndmills, 2004), 121-37.
} 
the Barbadoes. ${ }^{34}$ This passage implies that transportation was either a suspension of the death sentence or a penal pardon. The criminalization of Irish confederate soldiers is of a piece with English perceptions of the Irish Catholics as barbarous, rebellious subjects deserving of conquest. ${ }^{35}$ Historians have occasionally misinterpreted other evidence of transportation as punishment for treason; in fact, this reasoning was remarkably uncommon. ${ }^{36}$ In the case of the Irish Catholics, two other forms of migration have confused the study of how prisoners of war were put to work. Most available records on transportation of the Irish as convicts to the American colonies pertain instead to civilians who resisted transplantation, or the requirement to move west of the River Shannon to poorer farming land. Transplantation refusers were convicted in the assizes and could have their capital sentences commuted to transportation to the West Indies. ${ }^{37}$ Meanwhile, Irish Catholic soldiers more commonly migrated east to Europe after surrendering. This established practice was not about criminal conviction. It was once again contractual in nature. The articles of surrender were signed by captains who agreed to transport their regiments wholesale to Europe, where they might join the army of any country that was 'in amity' with England. Thirty-four thousand Irish men are believed to have left their home country under these conditions. Similar proposals circulated in mid-1650s Scotland, but do not seem to have been carried out. The reasoning behind these European transportations was eminently practical.

\footnotetext{
${ }^{34}$ Abbott, ed., The Writings and Speeches of Oliver Cromwell, ii, 127, see also 124.

${ }^{35}$ Patrick J. Corish, 'The Cromwellian Regime' in T.W. Moody, F.X. Martin, and F.J. Byrne (eds.) $A$ New History of Ireland, 9 vols. (Oxford, 1976), iii, 336-85.

${ }^{36}$ Beckles, White Servitude, 53 cites a Council of State Order Book from May 1656 as evidence of large-scale transportation of soldiers whom he takes to be prisoners of war convicted of 'high treason.' Closer examination shows the planned transportation of 1,200 men by Martin Noell to be the movement of soldiers from regiments serving the Protectorate in Ireland and Scotland to Jamaica. The state presumably wanted these soldiers to hold on to the recently claimed island: TNA, SP 25/77, p. 140-42, 150-51.

${ }^{37}$ John P. Prendergast, The Cromwellian Settlement of Ireland (London: Constable, 1996 [1865]), 52, 63-65; John Cunningham, Conquest and Land in Ireland: The Transplantation to Connacht, 1649-1680 (Woodbridge, 2011), 74-75.
} 
The English state stood to gain enhanced security by lowering the number of experienced soldiers resident in the restive Celtic regions. ${ }^{38}$

The majority of the prisoners of war who went to work did so not as convicts but rather under the guise of freely-entered contracts. Although free consent and captivity were dissonant, the law allowed for their combination in the case of impoverished, lower-status people. Most captives who became colonial servants entered written service indentures. In fact, their contracts — if not their circumstances — were the same as civilian indentured servants who emigrated from England to the colonies. ${ }^{39}$ Thus in December 1648, commander-in-chief of the parliamentarian New Model Army, Sir Thomas Fairfax, allowed the London citizen Richard Arnold to recruit royalist English prisoners from the defeated garrison in Colchester as servants for Barbados. Shortly thereafter, a witness entered a deposition in the Lord Mayor's Court of London, which routinely recorded evidence on business matters that might later be disputed. The witness deposed that nineteen men from the garrison had contracted to serve Arnold in Barbados, and that 'without any constraint or inforcement every of the said persons did freely tender themselves $\&$ did signe $\&$ seale Indentures to the said Richard Arnold as is usuall in such cases, \& were afterwords conducted to shipp board to bee accordingly transported to the said Island. ${ }^{40}$ The reference to signing and sealing contracts 'as is usuall' implies that standard servant contracting procedures held

\footnotetext{
${ }^{38}$ On the Irish: TNA, SP 25/31, p. 87, 93; Smith, Colonists in Bondage, 163-64; Ó Siochrú, God's Executioner, 216-19; Éamonn ó Ciardha, 'Tories and Moss-Troopers in Scotland and Ireland in the Interregnum,' in Celtic Dimensions of the British Civil Wars, John R. Young (ed.), (Edinburgh, 1997), 145 and 153-54. On the Scottish: C. H. Firth, ed., Scotland and the Commonwealth: Letters and Papers Relating to the Military Government of Scotland, from August 1651 to December 1653 (Edinburgh, 1895), xlix; and F. D. Dow, Cromwellian Scotland, 1651-1660 (Edinburgh, 1979), 132-33; John Morrill, Oliver Cromwell and the English Revolution (London, 1990), 164-65.

${ }^{39}$ John Wareing, Indentured Migration and the Servant Trade from London to America, 1618-1718: "There Is Great Want of Servants" (Oxford, 2016).

${ }^{40}$ London Metropolitan Archives, CLA/024/06/002 (3 Dec. 1648), calendared in Peter Wilson Coldham, ed., Lord Mayor's Court of London Depositions Relating to Americans, 1641-1736 (Washington, D.C., 1980), 80. Arnold had entered a variety of service indentures as a master: he had registered eleven apprentices who were bound by indentures to serve him in the City of London: Cliff Webb, London Livery Company Apprenticeship Registers, Vol. 43, Vintners' Co. 1609-1800 (London, 2006), passim.
} 
for prisoners of war. The deponent found the nature of the prisoners' contracts worthy of comment, possibly due to leading questions posed by the court (now lost). He considered the prisoners to have entered service contracts of their own free will - even if they did not have a plausible option to refuse. However, the fact that this deposition was recorded at all suggests that Arnold feared that the men he transported might later contest their servitude. He asked a subordinate to depose so that he could better establish the freely contracted nature of that servitude and thus defend against future complaints based on unwillingness.

Whether in England or abroad, most early modern servants with multi-year terms to English masters entered indentures. Several aspects of indentures gave masters recourse to enforce their servants' obligations. These contracts were created in duplicate, signed by witnesses, and often made in front of a magistrate charged with assessing whether both parties were willing and able to contract under the law. The counterparts were distributed to the master and either the servant or a local officeholder. They served as evidence of consent, years after the agreement was formalized. In one case, the town recorder of Watertown, Massachusetts copied out the indenture of a transported Scot when his contract was transferred to a new master. This record shows that on 15 October 1652, Alexander Gordon did 'covenant agree and promise to Serve' Samuel Stratton or his sons for six years: 'wherein I do promise to do him true and faithfull service not to absent myselfe day or night out of his family dureing the time of Apprentiship aforesaid without his Licence or consent, that I will not entangle or engage myselfe in any way of Contracts or mariage dureing the aforesaid time, all his Lawfull demands and injunctions I do promise to fulfill to my uttermost power and abilities... ${ }^{41}$ These terms were all standard-issue for service indentures. But the contract lacked reciprocal promises of clothes, food, or freedom dues for the servant. Such terms often

\footnotetext{
${ }^{41}$ Middlesex Registry of Deeds, 'Record books of the registry of deeds, Middlesex County, Massachusetts, 1649-1900,' vol. 1, p. 61 (digitized on familysearch.org); cited in Banks, 'Scotch Prisoners Deported to New England,' 25.
} 
featured in civilians' colonial service indentures; their absence here suggests that prisoners' contracts could have less specificity about the obligations owed to them by their masters. ${ }^{42}$

Parliament itself used the purported consent of prisoners of war as a tool for legitimizing their transportation policy. On 31 October 1648, in response to a petition, the House of Lords reviewed an account of two ships full of Scottish prisoners, which had been authorized to go to the foreign plantations by the committee for prisoners in the Commons, but still awaited the Lords' approval. The Lords noted that 'the said Persons are all willing to go, and the Persons that shipped have cloathed them, and provided all Necessaries for them. ${ }^{43}$ It is possible that the Lords could see the Scots' acceptance of clothing and food offered to them as a form of contractual consideration - a legal doctrine under which the exchange of something of value made a contract legally binding for both parties. ${ }^{44}$ People of upper status often thought that the promise of basic necessities to those in desperate need would naturally produce those peoples' acquiescence to work. The Lords' investigation offers one of the first examples of this dynamic of social relations playing out in the context of war captive management. The committee found all to be satisfactory, and the Lords gave permission for the ships to depart.

The servant status of the transported prisoners in the colonies soon became vexatious. In a 18 September 1655 letter to Oliver Cromwell (now the Lord Protector), Barbados Governor Daniel Searle expressed doubts about the wisdom of sending such men as servants to the small sugar plantation colony. For one thing, they could start another rebellion. The authority of the Protectorate in Barbados was fragile. The governor thought of the Irish and Scots as a fifth column. His fellow planters in Barbados petitioned the Council of State to

\footnotetext{
${ }^{42}$ James Horn, Adapting to a New World: English Society in the Seventeenth-Century Chesapeake (Chapel Hill, 1994), 66-69.

${ }^{43}$ Journal of the House of Lords, (London, 1767-1830), x, 572.

${ }^{44}$ A. W. Brian Simpson, A History of the Common Law of Contract: The Rise of the Action of Assumpsit (Oxford, 1987), 320-26.
} 
provide for their defence, mentioning 'three thousand Irish \& fowre thousand Scotts hearetofore prisoners of warr inclineing to mutinie \& Rebell for theire owne enlargement, \& readie to assist against their patrons if any enemy should appeare beefore ye Island. ${ }^{45}$ But Searle's immediate worry in his letter centered on the practical incompatibility of servitude with imprisonment. He reported that some royalists transported to the island, presumably three or more years ago, had since left and gone home. He asked not to be held responsible because he only just received orders to keep these transportees in Barbados. As far as he was concerned, such prisoners had legally transformed into servants upon entering their indentures and could gain their freedom just like other servants, by serving time or purchasing their redemption. Then they were, in Searle's words, 'free to stay or depart hence. ${ }^{46}$ Indeed, the legal status of transported prisoners of war and other deportees ended up being the same as all other indentured servants. ${ }^{47}$ War captives placed into transatlantic service indentures under the guise of free contract blended in with servants who had been procured from civilian populations in the British Isles.

And yet in the letter to which Searle was replying, Cromwell had insisted that the first group of servants could be legally kept in exile no matter if they satisfied contracts with their masters. His exchange with Searle confirms what one would expect: that free labour contracts posed problems when applied to prisoners of war, not only from the perspective of captives who had no choice but to consent to serve, but also from the perspective of security for the Protectorate. The scale and geographic extent of war captives in service suggests that, on balance, the state saw this risky policy as worthwhile and defensible.

\section{III}

\footnotetext{
${ }^{45}$ TNA, CO 1/69, no. 2 (1655?).

46 Thurloe State Papers, iv, 39, original in the Bodleian Library, MS Rawl A 30, p. 363-66.

${ }^{47}$ Beckles, "A 'riotous and Unruly Lot'," 514.
} 


\section{The Bedford Level Prisoners as Willing Workmen}

The best-documented instance of prisoner service in the period comes from the East Anglian fens. From 1651 to 1653 , two to three thousand Scottish and Dutch prisoners worked for the Society of Adventurers, led by the $5^{\text {th }}$ earl of Bedford. This company's mission was to drain the marshy land of the Bedford Level or Great Level. Like the poorest English labourers, foreign prisoners in the Bedford Level were required to consent and could not refuse. This dynamic had been foreseen to some degree several years before. When Parliament passed the Drainage Act of 1649 to legitimize the Bedford Level company in their ongoing undertaking, it included the justification that drainage would make the region suitable for a variety of agricultural and pastoral ventures and thus 'will relieve the Poor, by setting them on work.' 48 In 1651 'the poor' came to include Scottish soldiers captured in battles over a hundred miles away. State papers show that the Council of State understood the captives to be dependent upon them for provisions. ${ }^{49}$

When the Society of Adventurers took these prisoners off the hands of the government, it seems that they offered the prisoners verbal service contracts like those used with local servants. Company records described their ideal prisoners as 'willing' workers, even though captivity, violence, and threats of execution severely constrained the prisoners' choices. This language of free contract positioned the entire prisoner employment policy not within the laws of war but instead within an ideological position that hierarchical social relations were based on consent.

48 'An Act for drayning the Great Level of the Fens' May 29, 1649 in C.H. Firth and R.S. Rait, eds., Acts and Ordinances of the Interregnum, 1642-1660, 3 vols., (London, 1911), ii, 130-39. See also Ash, The Draining of the Fens, 213-14, 265-66.

${ }^{49}$ CSPD 1651, 427, 431-33, 443-44; CSPD 1652-1653, p. 97-8, 146-8, 196, 219, 233, 250; TNA, SP 25/23, p. 72; SP 25/69, p. 270. 
In October 1651, the English Council of State first offered some of the commoners amongst the Scottish prisoners from Worcester to the Society of Adventurers. ${ }^{50}$ The company proceedings record that the board sent some employees to look at the prisoners held in Erith, on the Thames, and 'to entertayne so many of them as are willing to be imployed in the service of the Companie on the workes. ${ }^{51}$ The board took two weeks to negotiate a contract with the council. The council granted the company access to the prisoners gratis because the state benefited enough from saving maintenance costs. However, according to minute books held by both institutions, the contract was to include a clause providing that the officers of the company would pay out a bond to the state for every runaway beyond the first ten percent. ${ }^{52}$ This clause implied that the Council of State retained some right to retrieve the prisoners later, perhaps to use them in an exchange. A couple of weeks later, another company employee went to York with a remit to gather the healthy, single prisoners who were 'willinge \& accustomed to labour.' ${ }^{53}$ The company recruiters in Erith and York, instructed to find willing labourers, most likely gathered the lower-status men who seemed most physically fit and perhaps said a few words about the service expected of them in exchange for food, clothes, housing, and wages. Whether or not the recruiters and prisoners did form a verbal agreement — one both sides recognised as such — cannot be known, but the company board chose to refer to the prisoners as though they had entered such contracts. In early November, the Bedford Level board members discussed whether they wanted to take on additional 'Scotch workemen' and resolved to take one thousand. ${ }^{54}$ The minutes of these discussions slipped briefly into calling these men 'workmen' instead of 'prisoners.' This

\footnotetext{
${ }^{50}$ Gardiner, History of the Commonwealth and Protectorate, vol. 2, 44-47; quote at 47.

${ }^{51}$ Cambridgeshire Archives, Cambridge, (hereafter CA), R59/31/9/5, f. 111 ${ }^{\mathrm{r}}, 1$ Oct. 1651.

52 TNA, SP 25/23 p. 9, 25, 27-28, 31 and CA, R59/31/9/5, f. 115v 14 Oct. 1651.

${ }^{53}$ CA, R59/31/9/5, f. $117^{\mathrm{v}}, 16$ Oct. 1651.

${ }^{54}$ CA, R59/31/9/5, f. $129^{\mathrm{r}}$, 5 Nov. 1651.
} 
word choice fits with a common tendency among English gentry and peers to see common soldiers and sailors as natural workmen who ought to labour based on their social status. ${ }^{55}$

The captors applied several legal frameworks to these prisoners, with different emphases as it suited them. Most obviously, prisoners of war fell under martial law, which dictated that they should not be killed, but rather captured and then ransomed or exchanged. Military codes from the period say nothing about whether prisoners should be set to work while in custody. ${ }^{56}$ On that topic, captors looked elsewhere. When the prisoners entered into service relationships with the Bedford Level company, they were treated as if they were paupers and subjected to the poor law and master-servant law, too. ${ }^{57}$ The council and the company could more easily justify putting captive common soldiers to work because captivity made these Scots dependant on charity to live. As was generally the case with early modern inmates, the prisoners had been segregated by status, with officers and those with money or credit held in different locations, with higher per diem spending on their maintenance. ${ }^{58}$ Thus common prisoners were a visually and conceptually distinct category from gentlemen prisoners, and vulnerable to forced labour.

Only the lower-status prisoners were taken by the company to the fens. These men had little possibility of refusing work, not only practically but also ideologically. According to the social expectations and moral thought of the period, the lower sort of people - those without property or income - should consent to serve because work was good for them. Masters cast the duty of work as a privilege that enabled the poor to live. They gave enforced

\footnotetext{
55 John Hatcher, 'Labour, Leisure and Economic Thought Before the Nineteenth Century,' Past \& Present 160, no. 1 (August 1998): 64-115; Keith Wrightson, Earthly Necessities: Economic Lives in Early Modern Britain (New Haven, 2000), Ch. 14.

${ }^{56}$ Matthew Sutcliffe, The Practice, Proceedings, and Lawes of Armes (London, 1593), Ch. XXI, Pt. 8, p. 336; Thomas, earl of Arundel, Lawes and Ordinances of Warre (Newcastle, 1639), 19; Robert, earl of Essex, Laws and Ordinances of Warre (London, 1646), C3v; see also John M. Collins, Martial Law and English Laws, c.1500-c.1700 (Cambridge, 2016), Ch. 5.

${ }^{57}$ Such a jump need not rely only on English laws: see Annabel S. Brett, Changes of State: Nature and the Limits of the City in Early Modern Natural Law (Princeton: Princeton University Press, 2011), 25-26.

58 TNA, SP 25/96, p. 513, SP 25/22, p. 69, and SP 25/23 p. 49.
} 
servants food, shelter, and sometimes wages, all of which they expected the servants to receive gratefully. In the self-serving logic of the providers, the prisoners' abjection in prison made them not only natural labourers but also natural labourers in need of a job. The desperate prisoners had the ability to freely consent to serve, but not to refuse. Refusal would simply prolong their imprisonment.

In order to compel these imprisoned common soldiers to enter into service willingly, the board gave them the same options as those given to the English paupers who entered compulsory, contractual service relationships with private masters and mistresses, under the long-lasting poor laws of 1563,1598 , and 1601 . These poor laws were still very much in force by the mid-seventeenth century. ${ }^{59}$ The 1563 Statute of Artificers required people who could not live of their own means to acquiesce to a master who requested their service. It empowered local magistrates and officeholders to imprison refusers until they consented to serve. The poor relief statutes of 1598 and 1601 authorized churchwardens, overseers of the poor, and justices of the peace to place poor orphaned children into parish apprenticeships until they reached their majority. Justices could also place adults into shorter-term agricultural and domestic service contracts. The definition of pauperism was largely in the eye of the beholder; it could change dramatically from place to place and person to person. Officers could theoretically require the service of poorer people upon their own discretion, interpreting precarious subsistence as idleness. Extending the logic of the poor law to foreign prisoners of war was a further exploitative expansion of a law that was designed to benefit those who held property. ${ }^{60}$

\footnotetext{
${ }^{59}$ Christopher Durston, Cromwell's Major-Generals: Godly Government during the English Revolution (Manchester, 2001), 158; Tim Wales, 'The Parish and the Poor in the English Revolution,' in The Nature of the English Revolution Revisited: Essays in Honour of John Morrill, ed. Stephen Taylor and Grant Tapsell (Woodbridge, 2013), 53-80. More research is needed on enforced service by the civilian English poor during the 1650 s.

${ }^{60}$ The Statute of Artificers, 5 Eliz. c. 4 (1562-3); An Act for the Relief of the Poor, 39 Eliz. c. 3 (1598); and An Act for the Relief of the Poor, 43 Eliz. c. 2 (1601), further endorsed and refined for the City of London in parliamentary ordinances for relief and employment of the poor, passed on 17 December 1647 and 7 May
} 
Compulsory service under the poor law was intended to supply much-needed labour; it was justified as a means to solve poverty and to reform the poor. The policy of conscription in the fens also responded to labour shortages. In the Bedford Level, the local labouring population had all but abandoned the drainage project after their wages went unpaid. ${ }^{61}$ The number of young men in the area had presumably also been reduced by the previous decade of warfare. While the Society of Adventurers could have tried to use the poor law to compel some local commoners to work, employing the prisoners of war was an easier option. The prisoners were alienated from their home communities. As strangers and captives, they were easier to dominate. The prisoners were not a cheaper labour source - if anything they were more expensive due to the extra cost of transport, clothing, and housing. They were simply the most available option in these years of firm local resistance to the drainage project.

The fact that the Bedford Level board members sought to procure prisoners on multiple occasions shows how much they wanted these prisoners' labour. In addition to those from Erith and York, the company received prisoners from the Battle of Dunbar. ${ }^{62}$ The records are vague on numbers, but perhaps a total of 1,500 to 2,500 Scottish prisoners went to the Bedford Level between October and December 1651. By May 1652, most of them had departed the project. ${ }^{63}$ Presumably the state required the company to release them from their obligations to work after the war with Scotland concluded, making these prisoners distinctly

1649: Firth and Rait, eds., Acts and Ordinances of the Interregnum, i, 1042-45 and ii, 104-10. See also Judith M. Bennett, 'Compulsory Service in Late Medieval England,' Past \& Present 209, no. 1 (November 2010): 751; Paul Slack, Poverty and Policy in Tudor and Stuart England (London, 1988), 29-31, 128; Hindle, On the Parish?, Ch. 3; Tim Wales, "Living at Their Own Hands": Policing Poor Households and the Young in Early Modern Rural England,' Agricultural History Review 61, no. 1 (June 2013): 19-39. For the Atlantic context see David Eltis, 'Labour and Coercion in the English Atlantic,' 209-10; Robert J. Steinfeld, The Invention of Free Labor: The Employment Relation in English and American Law and Culture, 1350-1870 (Chapel Hill, 1991); Douglas Hay and Paul Craven, eds., Masters, Servants, and Magistrates in Britain and the Empire, 1562-1955 (Chapel Hill, 2004), Chs. 1-3.

${ }^{61}$ Lindley, Fenland Riots, 175.

${ }^{62}$ CA, R59/31/9/5, f. 160v, 31 Dec. 1651; Gardiner, History of the Commonwealth and Protectorate, ii, $62-63$.

${ }^{63}$ CA, R59/31/9/5, f. $224^{\mathrm{v}}$. 
lucky compared to their former comrades who, rather than working in the fens, had been transported to colonial servitude with no provision for their return.

However, months later, the company still needed more labourers desperately enough that they took on newly captured Dutch sailors. The English began fighting with the Dutch in the Channel in July 1652, after months of awkward diplomatic exchanges following the passage of the Navigation Act, which prohibited non-English ships from importing most goods into Commonwealth-controlled territories. At the Battle of Portland in February 1653 the Commonwealth took some 1,500 Dutch prisoners. ${ }^{64}$ Over the course of the war, 4,000 Dutch captives ended up in England. ${ }^{65}$ The Council of State, emboldened by past success with allowing private masters to employ war captives who hailed from within the Three Kingdoms, moved to doing the same with the Dutch — on a rather more international stage. Some Dutch prisoners were put to work in coal shipping and dockyards and as recruits in the English navy. An intercepted letter from the Dutch ambassador in London to the Zeeland council said of the Dutch prisoners in London: 'those that are well in health are fetcht away day after day under colour of setting them to work in their timber wharfs upon the river, and about the building of their ships; but it is to be feared, that it is really to send them on shipboard. ${ }^{96}$ There was a surplus of Dutch prisoners beyond those who could be put to work on shipboard or in shipyards. In March, the Council again approached the drainage company with an offer of prisoners, now Dutch, for their works. The Bedford Level board was slower to agree to participate this time, however. It only did so several months later, perhaps as a last resort, after it failed in its struggles with local East Anglian labourers. ${ }^{67}$ In June, 440 Dutch

\footnotetext{
${ }^{64}$ TNA, SP 18/34, f. $73^{\mathrm{r}-\mathrm{v}}$ (CSPD 1652-1653, 212-13).

${ }^{65}$ Rommelse and Downing, 'Victims,' 661-62. Dutch deputies in England reported that amongst the prisoners were also 'Germans, Bremeners, Hamburghers, Westphanlians, nay even Swedes and Danes,' in Thurloe State Papers, i, 499, original in the Bodleian Library, MS Rawl. A 6, p. 349.

${ }^{66}$ Rommelse and Downing, 'Victims,' 663; Thurloe State Papers, i, 369, original in the Bodleian Library, MS Rawl A 4, p. 274 (22 July 1653).

${ }^{67}$ CA, R59/31/9/6, Mar.-Oct. 1653. Lindley, Fenland Riots, $186-87$ refers to 1653 as the 'crisis year.'
} 
prisoners went to work in the Bedford Level. ${ }^{68}$ Those who stood to gain from the labour of prisoners had first tested the application of compulsory contract to a population of Scots at once protected by their status under the laws of war and exposed by their lack of an empowered sovereign to challenge the English government. The experiment had been dubiously successful, and its extension to the Dutch was fraught with far more risk of prisoner resistance in concert with diplomatic catastrophe.

The Society of Adventurers and the Council of State framed both the Scottish and Dutch prisoners' service as a mutually beneficial arrangement, just as compulsory service for the poor was said to be. And the common captives were seen as poor: for instance, the Dutch ambassadors in London described the prisoners of war there as "our poor miserable people," reliant on charity from a Dutch congregation in the capital. ${ }^{69}$ Board minutes represented the prisoners' recompense and wages as exceeding what was merely required for subsistence. Implicitly, if this was the case, it was easier to see the prisoners as willingly contracted servants, not forced labourers. Thus, the company proceedings initially expressed a hope that the Scottish prisoners would welcome their opportunity to work, because they would be well recompensed: 'wee did hope that they might have byn brought into so good disipline as receiving a fittinge reward from us for theire labour they might have had...iust cause to blesse god for the parliaments mercy to them. ${ }^{70}$ Indeed, the minute book shows that the Scots received shirts, caps, shoes, and lodging from the company in exchange for their work. ${ }^{71}$ They also received wages, probably from the start and certainly by May $1652 .{ }^{72}$ With the Dutch prisoners, the board minutes recorded that they had been taken on with 'the intent

${ }^{68}$ CA, R59/31/9/6, 21 June 1653, f. $98^{\mathrm{r}}$.

${ }^{69}$ Thurloe State Papers, i, 415.

${ }^{70} \mathrm{CA}, \mathrm{R} 59 / 31 / 9 / 5$, f. $115^{\mathrm{r}}$, Oct. 1651. Ash, The Draining of the Fens, 268 interprets this passage to mean that the Scots were paid a very low wage. The payment of wages is only definitive by May 1652 (f. $215^{\mathrm{r}}$ ), and how much each Scot received is never stated.

${ }^{71}$ CA, R59/31/9/5, f. $114^{\mathrm{v}}, 117^{\mathrm{r}}, 119^{\mathrm{v}}, 165^{\mathrm{v}}, 177^{\mathrm{r}}, 215^{\mathrm{r}}$.

${ }^{72}$ CA, R59/31/9/5, f. $215^{\text {r }}$. 
they may bee best disposed of from tyme to tyme for the service of the Company' in exchange for which they would be given room, board, and forty shillings a week, a sum which was probably divided amongst them. ${ }^{73}$ The Council of State had dictated that the Dutch prisoners were to be paid at the same rate as other labourers in the drainage project. ${ }^{74}$ Like English paupers, the prisoners' subjection to coercion did not invalidate their contracts. They not only had been procured from prison. They also stood subject to corporal and, in some cases, capital punishment for disobedience throughout their tenure in the fens. More so than with paupers' vulnerability to violent discipline under the poor law and masterservant law, the prisoners' position within overlapping and competing legal frameworks proved to be doubly to their disadvantage. Even while receiving the charity of food, clothes, housing, and wages in exchange for work, the Scots in the fens continued to be identified as prisoners and subjected to martial law. In November 1651, a month after the first batch of prisoners were sent to the fens, the Council of State passed an order for Scottish runaways to be summarily executed; the Company then directed a provost marshal assigned to the works to carry out this 'justice. ${ }^{75}$ A runaway Scot could be executed on the grounds that he had broken his oath to be a faithful prisoner, a customary part of giving quarter to the enemy. ${ }^{76}$ The company minutes do not record the performance of capital punishment, only the threat of it, but either had coercive power.

Poverty and gratitude were not sufficient to discipline the Dutch, either, and the company duly sought additional coercive powers to use on these prisoner-employees, as well. In July 1653 the company wrote to their main contact in the government, John Thurloe, to ask for 'a power given to the Comander in cheife [of the soldiers who supervised the

\footnotetext{
${ }^{73}$ CA, R59/31/9/6, f. $98^{\mathrm{v}}$.

${ }^{74}$ TNA, SP 25/69, p. 270, 11 June 1653.

${ }^{75}$ CA, R59/31/9/5, f. 140 v, 19 Nov. 1651.

${ }^{76}$ Ambühl, Prisoners of War, 106-109; Donagan, 'Prisoners in the English Civil War,' 29.
} 
prisoners] to punish them by putting them into the Goale or otherwise as shall bee thought fitt by the Lord Generall or Councell otherwise the soldyer will doe nothing and so tell us. ${ }^{77}$ 'Goale or otherwise' probably meant imprisonment and corporal punishment, not capital punishment. With both the Scots and Dutch, the board members implicitly categorized the plebeian soldiers and sailors as natural labourers, but assumed that the best guarantee of their disciplined, profitable labour was violence. ${ }^{78}$

As dire as this situation appears to have been, board members did not wish to enslave prisoners of war, nor to be seen to do so. The company developed its undertaking in a context where gentry and middling people increasingly chose to stress poor commoners' free will to serve, without what appears to us to be the necessary corollaries, namely, their right to choose who to serve, how to serve, and indeed whether to serve at all. That English paupers should agree to enter compulsory service contracts was established. The state and its collaborators then extended this concept to apply to foreign prisoners of war. Nevertheless, the board was dogged by the fact that these contracted relationships were founded on absolute submission, and relied on ongoing, violent domination.

\section{IV}

\section{Opposition to Prisoner of War Labour in the Bedford Level}

The prisoners themselves and their neighbours in the fens called attention to the clash between the language of free contract and the use of coercion. They instead drew on the language of duress and the customary laws of war to reject the employment of war captives. A variety of factors drove both the prisoners and local fen people to articulate opposition in

\footnotetext{
${ }^{77}$ CA, R59/31/9/6, f. $107^{\mathrm{r}-\mathrm{v}}$, 17 July 1653.

${ }^{78}$ See also Trevor G. Burnard, Planters, Merchants, and Slaves: Plantation Societies in British America, 1650-1820 (Chicago, 2015), Chs. 1-2.
} 
this way: self-preservation, regulation of local resources, and a principled resistance to the violation of the customary laws of war.

From the prisoners' perspective, the experience of being marched by armed escort to the fens, outfitted in distinctively colored caps and shirts, and supervised by a provost marshal as they undertook the work of building dykes must have felt like a punishment, or at best a small mercy. In response, many ran away. They caused a serious problem, so much so that the company planned to print and post five hundred copies of the November 1651 order that empowered a provost marshal to execute runaways. The minutes stipulated that 'they are to bee dispersed all over the Levell and fixed upon some convenient place in every towne to the intent that Justice may bee done and marshall Law executed. ${ }^{79}$ Five hundred posters would have been enough for every parish in the Bedford Level to have about ten copies. The company wanted this announcement to be unavoidable for people who lived around the drainage work sites.

The fenland neighbours deeply opposed the drainage project because it threatened their common lands and regional economy. To bring the works to an end they rioted, destroyed the dykes, and petitioned Parliament. ${ }^{80}$ They saw the arrival of prisoners of war on the works as a new point of contestation. These prisoners had been invited to the region to help speed along the enclosure and improvement process. The neighbours were therefore more likely to assist the Scottish runaways than to report them. In offering this assistance, locals did not aim to liberate the prisoners out of sympathy for their plight, but out of antipathy for the project. The local accomplices to runaways wanted to get the Scots out of their land in order to prevent them from advancing the drainage and taking up resources.

\footnotetext{
${ }^{79}$ CA, R59/31/9/5, f. $144^{\mathrm{r}}$, 24 Nov. 1651.

${ }^{80}$ For example, The Humble Petition of the Inhabitants of the Soake of Peterborow... against the Undertakers There, etc. ([London], 1650, STC R178300). See also Lindley, Fenland Riots, passim.
} 
Indeed, the locals feared that if the Company made the prisoners into servants in more than just rhetoric, these newcomers could make claims on the surrounding community, as other servants did. In late May 1652, the Company received a petition from a Mr. Drewry, 'on the behalfe of the Country' in which he complained that the Scots had several women amongst them 'bigge with child.' The letter demanded that the company take care of these women and their babies so that they would not request parish poor relief. ${ }^{81}$ The pregnant women were most likely soldiers' wives who had followed their husbands to war and then to prison - a normal feature of early modern European warfare. Once pregnant, these women embodied the possibility that the Scots might settle in the region. If the parishes refused to offer them charitable assistance, it fell to the company to either set these families free or to act like a parish, once again treating their prisoners as paupers-turned-servants.

Presumably for the same reason, the fen people also assisted Dutch runaways and sometimes instigated their escapes. The July 1653 letter of the board to Thurloe complained that 'the Dutch prisoners not onely refuse to worke but are encouraged by the Country people of Swaffam Waterbeach Collenham and other places who are opposite to this worke of dreyninge to run away hidinge them in the Corne., ${ }^{82}$ These neighbours strategically opposed the drainage project by letting the company's captive workforce loose. Playing accomplice to this marronage was just one of many forms of resistance to drainage: a month later, residents of these same villages were out in force, destroying dykes with the tacit support of local grandees. $^{83}$

${ }^{81}$ CA, R59/31/9/5, f. 224v, 29 May 1652, cited in Ash, The Draining of the Fens, 269 as evidence that most Scots did not run away. The 'Mr. Drewry' here was probably Edmund Drury, a local gentleman involved in the August 1653 Swaffham Bulbeck riots: Lindley, Fenland Riots, 179. Women and boys are recorded as being amongst the Scottish prisoners from the start of their tenure in the fens: CA, R59/31/9/5, f. 116 .

${ }^{82}$ CA, R59/31/9/6, f. $107^{\mathrm{r}}$, 17 July 1653, discussed in Lindley, Fenland Riots, 176-77. Swaffham Bulbeck is the full name of the village.

${ }^{83}$ TNA, SP 18/39, f. 175-76, 30 Aug. 1653 (CSPD 1653-1654, 115-16). 
Although self-preservation motivated the neighbours and the Dutch captives to oppose setting prisoners of war to work in the fens, both looked to the laws of war to justify their resistance and petition for a change. The letter to Thurloe and the Council of State went on to reveal this justification, reporting that the Dutch 'say they are prisoners of warre and ought not to bee inforced to labour, and in this they have also encouragmt from the Country. ${ }^{84}$ This line is a rare popular articulation of the customary law of war that prisoners of war should not be enslaved. ${ }^{85}$ The point mattered enough for the board members to make it twice: once in this letter, and again in a covering letter for Thurloe alone. There they added the postscript with which this article began: 'The Dutch prisoners are so stubborn \& they will not work, beinge possest by the Country, that they beinge prisoners at warre, they are to bee mainteyned by them that keepe them So that barely to keepe them alive they spend more than they earn., 86

This version of the report went further, to include not only the negative principlethat prisoners of war should not be put to work — but also the positive: the Dutch and 'the Country' or fen people asserted that the board had an obligation to maintain their captives. Whether this demand meant that prisoners ought not to have been transferred out of state hands is unclear, as the state relied on middlemen to maintain civilian prisoners in jails, as well. But what is clear is that the prisoners objected to being expected to cover the cost of their subsistence and produce profits for their 'keepers.' The rather dour line that the prisoners cost more than they profited the company reveals two things that the company board might not have intended to let slip. For one, the prisoners were generating some value — just not enough to please their new masters. For another, the prisoners were held in

\footnotetext{
${ }^{84}$ CA, R59/31/9/6, f. $107^{\mathrm{r}-\mathrm{v}}$, 17 July 1653 (the company minutebook); see also Thurloe State Papers, i, 358, original in the Bodleian Library, MS Rawl. A 4, p. 232 (the mailed version of the same letter).

${ }^{85}$ See also Donagan, War in England, 139 and Donagan, 'Atrocity, War Crime, and Treason in the English Civil War,' The American Historical Review 99, no. 4 (1994): 1146.

${ }^{86}$ Thurloe State Papers, i, 358.
} 
atrocious conditions. The prisoners remained in the fens for only a few more months, during which time the company records hardly mentioned them. ${ }^{87}$ No further evidence survives to show what happened next.

An unlikely coalition of people - the Dutch prisoners, their ambassadors in London, and their English neighbours in the Bedford Level — insisted on the protections offered by customary law and resisted the application of positive law to the war captives. They believed that captors should feed and house the prisoners as well as possible until an exchange was negotiated. The prisoners' special status should preserve them from having to work for their subsistence or for their captors' profit. Although their employers tried to enter a free labour contract with them, under their own logic that contract was unjust and illegal because they were prisoners of war. While their captors held the power of life and death over them, they could not freely consent to anything. The prisoners refused to act like paupers. They received the offers of work as neither charity nor opportunity, with the knowledge that customary law supported their position.

\section{V}

\section{The Competing Legalities of Prisoner of War Labour}

Although the English state rarely treated common captured soldiers during these wars as criminals and traitors, the possibility that they could be categorized in that way always lurked in the background ${ }^{88}$ Distinguishing the variations in treatment based on prisoners' allegiances further demonstrates the fluctuating and overlapping nature of the laws of war, English criminal law, and the poor law. ${ }^{89}$ As we might expect, the English government

${ }^{87}$ CA, R59/31/9/6, f. $110^{\mathrm{r}}$, 4 Oct. 1653.

${ }^{88}$ Donagan, 'Atrocity, War Crime, and Treason.'

${ }^{89}$ For a review of the current approaches to parallel legalities or multinormativity, see Thomas Duve, 'European Legal History - Concepts, Methods, Challenges,' in Entanglements in Legal History: Conceptual Approaches, Thomas Duve (ed.), (Frankfurt am Main, 2014), esp. 58-59. 
treated its rebellious subjects differently from captured foreign opponents like the Dutch. The English and Scottish prisoners of war were never criminalized in the way that the Irish captives at Drogheda had been in $1649 .{ }^{90}$ In 1651 the Council of State had considered putting some of their Scottish prisoners on trial. Ultimately the council did not follow through. ${ }^{91}$ All sides in the War of the Three Kingdoms generally chose to treat captured enemies as prisoners of war instead of as traitors. ${ }^{92}$ The decision not to take criminal proceedings against captives from the Three Kingdoms can be understood as a mix of profit-seeking opportunism, ethical restraint, and an aversion to tricky legal proceedings or possible retribution.

Meanwhile, the members of the Council of State never proposed the transatlantic transportation of captives taken in the First Anglo-Dutch War, even while they did funnel them into employment in the English fens and dockyards. The first reason was practical. Had merchants transported the Dutch prisoners "beyond the sea," they would have risked spoiling negotiations to conclude a war and create a commercial accord between two states that recognised each other's sovereignty. ${ }^{93}$ During the course of the war, the Dutch prisoners needed to be kept readily available for imminent exchanges or releases. Indeed, all of the surviving Dutch prisoners had left the Bedford Level even before the peace treaty was signed. Thus, on an international stage the English state demonstrated its intention to follow the laws of war and the customary exchange of prisoners. The fact that the state allowed these Dutch prisoners to go to work in England in the interim means that the ministers did not consider such employment to be a grave contravention of the laws of war. Their silence on the question of transporting the Dutch suggests that they knew that transportation and colonial

\footnotetext{
${ }^{90}$ Jenny Shaw, Everyday Life in the Early English Caribbean: Irish, Africans, and the Construction of Difference (Athens, Ga., 2013), 25.

91 TNA, SP 25/96, p. 547, 22 September 1651 (CSPD 1651, 449-50).

92 Donagan, 'Atrocity, War Crime, and Treason' esp. 1164.

${ }^{93}$ Rommelse and Downing, 'Victims,' 655-56 does not fully develop this idea, and proposes that the transportation of Scottish and Irish but not Dutch prisoners had as much to do with reducing the dangerous overcrowding of prisons as with retribution against conquered enemies.
} 
indentured servitude pushed the bounds of custom and violated widely accepted protections for prisoners. By contrast, Scottish prisoners in English hands were particularly vulnerable to violence and transportation to the English American colonies, even though the English did not legally categorize them as traitors. Their vulnerability came from defeat: after the Battle of Worcester, Cromwellian forces occupied Scotland as conquerers. ${ }^{94}$

Another telling contrast arose between the treatment of enemy soldiers and sailors taken in wartime, and those who were rebels in the eyes of the state, taken after 1653, when the wars in the Three Kingdoms had formally concluded. On 19 October 1654, the Council of State ordered for English, Irish, and Scottish 'pirates' in the Dorchester prison to be transported to Barbados, Bermuda, or other colonies, while 'the French or other strangers' be released. ${ }^{95}$ Another Council of State order from 3 September 1655 confirms that opponents to the regime taken at sea were now to be cast as pirates, instead of prisoners of war. The order calls for most of them to be transported to Barbados, 'saveing such of the most notorious actors amongst them as shalbe thought fitt to be sent to the Gaole to be tryed for their lives,' implying that the transportation would be summary punishment. ${ }^{96}$ In the Salisbury Rising or Penruddock's Rising of 1655, the Protectorate government sought to brand royalist conspirators as criminals and in some cases traitors. It settled for a far more ambiguous transportation without conviction or, apparently, contract. ${ }^{97}$ Similarly, the March 1655 executive orders to empty prisons in Plymouth and Tynemouth of 'prisoners taken at Dunbarr' by sending able-bodied men to Barbados give no justification. ${ }^{98}$ This decision to

${ }^{94}$ Dow, Cromwellian Scotland, Pt. 1; Donagan, ‘Atrocity, War Crime, and Treason,' 1139.

95 TNA, SP 25/75, p. 586. Calendared version cited by Beckles, White Servitude, 53.

96 TNA, SP 25/76, p. 264.

${ }^{97}$ On Penruddock's Rising see forthcoming work by Katherine Lazo on the problems with prosecuting royalist conspiracy as treason. Many alleged Salisbury conspirators were transported to Barbados without trial. Some petitioned for their redemption: Marcellus Rivers and Oxenbridge Foyle, England's slavery, or Barbados Merchandize (London, 1659, STC R209821); for the resulting parliamentary debate: J.T. Rutt, ed., Diary of Thomas Burton, Esq., 4 vols., (London, 1828), iv, 254-273.

98 TNA, SP 25/75, p. 705 and 733. 
transport opponents-in-arms as a summary punishment had long-lasting detrimental effects on the regime's reputation.

Royalist propaganda at the time, and memories of this period in the Restoration that followed, saw colonial transportation of royalist prisoners as invalidating the Protectorate's claims to authority and civility. They charged the Protectorate with acting as a barbarous enslaver of men. The printed sheet, 'A declaration by the royalists against the rebels of England, concerning prisoners taken at sea,' was composed on 30 December 1655 on the royalist fleet. It set up a stark difference between benevolent treatment of prisoners by royalists, who claimed to be conducting a just war to restore a rightful sovereign, with the treatment given by the usurping Protectorate. This illegitimate government was not keeping their royalist captives as 'prisoners of war' with the hope of exchange, but instead, 'do use them in like manner (or worse) as they deal with felons and other public malefactors amongst themselves... and most barbarously have sold and sent away many of those our friends (freeborn subjects to the crown of England) for slaves into some of the foreign plantations under the present power. ${ }^{99}$ The broadsheet goes on to threaten retribution to the prisoners that they (the royalists) take: these prisoners will also be sent to distant plantations or clapped in irons in 'stinking dungeons' unless their friends are immediately released. ${ }^{100}$ The weak position of royalists in the mid-1650s made these threats mere bluffs. English royalists during the mid1650 s and throughout the next several generations continued to represent the Protectorate as an enslaver of Englishmen. ${ }^{101}$

${ }^{99}$ Thurloe State Papers, iv, 360, original in the Bodleian Library, MS Rawl A 33, p. 644.

${ }^{100}$ Thurloe State Papers, iv, 360-1.

${ }^{101}$ James Fraser, Chronicles of the Frasers: The Wardlaw Manuscript...or, The True Genealogy of the Frasers, 916-1674, William MacKay (ed.), (Edinburgh, 1905), 388, 392; Thomas Blount, Boscobel, $3^{\text {rd }}$ edition (London, 1680), 24; LMA, COL/CA/1/1/74, f. 19v [Rep. 70]; The Bodleian Library, MS J. Walker c. 3, f. 38 and MS J. Walker c. 7, f. 26v , cited in Fiona McCall, Baal's Priests: The Loyalist Clergy and the English Revolution (London, 2016), 189-90; Mark Stoyle, "'Memories of the Maimed": The Testimony of Charles I's Former Soldiers, 1660-1730,' History 88, no. 290 (April 2003): 217. 


\section{VI}

\section{Conclusion}

The variable position of prisoners of war within the laws of the early modern world allowed both the state and masters to experiment with treating these prisoners like paupers who ought to serve, and serve willingly. In nearly all known cases of prisoner of war employment from 1648 to the formal peace of 1653 , the prisoners entered contracts as allegedly free agents, not as convicts. As seen in the case of the conscription of Scottish and then Dutch prisoners in the Bedford Level fen drainage company, English masters imagined that common prisoners could willingly agree to become labourers - motivated by wages and improved conditions, in conformity with the idea of commoners' natural servility. They chose this conceptual framing even as they had these prisoners supervised by a provost marshal and regularly threatened with corporal and capital punishment. Coercion and purportedly free labour contracts were perfectly compatible. That compatibility followed from the logic of the Elizabethan poor laws. Employment would, in the poor law approach, be mutually beneficial, sustaining the impoverished captives while supporting dyke construction, iron works, and plantations.

The key problem with this approach was that it made no allowance for prisoners to refuse to serve, and yet that was exactly what prisoners did. Opponents to prisoner employment dismissed free contract as a hollow expediency and instead emphasized the reliance on coercion to get these captives to cover their cost of living and turn a profit. These opponents, including prisoners themselves, promoted the customary laws of war and asserted that their service was extracted in contravention of those laws. Far from being incapable of refusing to serve, the prisoners asserted that in fact they had a special, protected status that made the offer of free service contracts incoherent. It was wrong to expect them to work. When the wars concluded in 1653 but rebellion and conspiracy continued, the Protectorate 
shifted its emphasis in application of the various relevant laws. Its summary transportation of rebels or political prisoners as criminals instead of willing workmen became one of the key delegitimizing features of its rule.

Despite the mid-century criticism of prisoner of war transportation and forced labour, several later governments used the same approach. In the Second Anglo-Dutch War, the newly restored Stuart regime placed healthy captured Dutchmen into service in transatlantic shipping and in England as craftsmen, day labourers, and sailors in domestic coal shipping. ${ }^{102}$ As in the 1650 s, their employment was not a matter of criminal punishment but rather an 'opportunity' to escape the cruel conditions in prison. The Dutch nearly reciprocated: in 1668 they threatened to put their English prisoners into service on ships bound to the East Indies. ${ }^{103}$ In 1685, the Monmouth rebels who opposed the accession of the Catholic James II and supported Charles II's illegitimate son the Duke of Monmouth, were instead transported as criminals. More than six hundred of those convicted at the assizes subsequently entered indentures and went to Barbados, Jamaica, and the Leeward Islands. ${ }^{104}$ The Williamite regime and its successors implicitly renounced this policy. After the Jacobite uprising of 1715, a similar number of captured Jacobites agreed, under great pressure from the government of George I, to their transportation to North America. ${ }^{105}$ These captives entered service contracts based on consent instead of conviction, just as captives in the late 1640s and 1650s had done. Indeed, throughout the late seventeenth and early eighteenth centuries, in much of Europe, captured common soldiers and sailors who refused to enlist in the opposing

\footnotetext{
${ }^{102}$ Gijs Rommelse and Roger Downing, 'State Formation, Maritime Conflict and Prisoners of War: The Case of Dutch Captives during the Second Anglo-Dutch War (1665-1667),' Tijdschrift Voor Sociale En Economische Geschiedenis 11, no. 1 (2014): 44.

${ }^{103}$ Gijs Rommelse, The Second Anglo-Dutch War (1665-1667): Raison d'état, Mercantilism and Maritime Strife (Hilversum, 2006), 187-88.

${ }^{104}$ Smith, Colonists in Bondage, 188-97; W. MacDonald Wigfield, The Monmouth Rebels, 1685 (Taunton, 1985); Mark S. Quintanilla, 'Late Seventeenth-Century Indentured Servants in Barbados,' Journal of Caribbean History 27, no. 2 (December 1993): 114-28.

${ }^{105}$ Smith, Colonists in Bondage, 197-203; Daniel Szechi, 1715: The Great Jacobite Rebellion (New Haven, 2006), 203-208.
} 
force were put to work in galleys, large-scale construction projects, mines, and dockyards, or commandeered for any crafts or professions they might know. ${ }^{106}$ More research is needed to determine the legal justification for this treatment in other regions and how it fit within shifting standards of warfare and coerced labour.

The significance of the contracts entered by the Bedford Level prisoners and their contemporaries lies not only in the precedent set for future wars. The way in which masters established control over these prisoners was also symptomatic of a shift in English ideas about labour in civilian and peacetime contexts. In the following decades, increasing numbers of transported civilian convicts from England had to consent to colonial indentures in order to receive a pardon and avoid capital punishment. ${ }^{107}$ The mid-seventeenth-century contract labour of common prisoners of war had further established the idea that the poor and the lower sort would naturally consent to serve and had no need for a meaningful option of refusal. This view proved useful in the experimental approach to both domestic and colonial labour procurement during the upheaval of the mid-century wars and political crisis. Amongst the conflicting sovereignties at play, and because of the interventions of ius gentium, status-based natural servility had not justified setting captured common soldiers and sailors to work. Contract — even without choice — offered more justification. Despite its risk and incoherence, the application of this reasoning continued to expand in the years to come.

\section{Sonia Tycko}

Harvard University

\footnotetext{
106 John Childs, 'Surrender and the Laws of War in Western Europe, c. 1660-1783,' in How Fighting Ends: A History of Surrender, ed. Holger Afflerbach and Hew Strachan (New York, 2012), 161-64.

${ }^{107}$ Innes, 'Transportation,' 12-14; Herrup, 'Punishing Pardon,' 131-33.
} 